\title{
AMMONIA INHIBITION IN THERMOPHILIC ANAEROBIC DIGESTION OF DAIRY CATTLE MANURE
}

\author{
Sutaryo $^{1}$, A. J. Ward ${ }^{2}$ and H. B. Møller ${ }^{2}$ \\ ${ }^{1}$ Faculty of Animal and Agricultural Sciences, Diponegoro University, \\ Tembalang Campus, Semarang 50275, Central Java - Indonesia \\ ${ }^{2}$ Department of Engineering, Aarhus University, Blicers Allé 20, DK 8830, Tjele - Denmark \\ CorrespondingE-mail: soeta@undip.ac.id
}

Received March 02, 2014; Accepted May 11, 2014

\begin{abstract}
ABSTRAK
Penelitan ini bertujuan untuk mengevaluasi perbedaan lima konsentrasi total amonia nitrogen (TAN) dan amonia terhadap produksi methan dan kinerja digester biogas pada kondisi thermophilic $\left(50^{\circ} \mathrm{C}\right)$. Penelitian menggunakan lima digester identik dengan pengisian subtrat secara kontinyu. Data diperoleh selama empat kali ulangan masa tinggal substrat di dalam digester. Data dianalisis dengan menggunakan fasilitas pengolahan data yang tersedia pada program Microsoft Excel. Lima konsentrasi TAN diperoleh dengan menambahkan urea sampai diperoleh konsentrasi TAN dan amonia yang diinginkan untuk selanjutnya konsentrasi tersebut dijaga dengan pemberian urea pada digester biogas disetiap harinya. Hasil penelitian menunjukkan adanya hubungan negatif yang sangat kuat antara konsentrasi TAN dan amonia terhadap produksi methan. Produksi methan berkurang sebesar 24, 30, 52 dan $66 \%$ pada digester yang mempunyai konsentrasi TAN 2.9, 3.6, 4.4 and $5.1 \mathrm{~g} / \mathrm{L}$ setara dengan 0.7 , $1.1,1.5$ and $1.8 \mathrm{~g} / \mathrm{L} \mathrm{AB}$. Konsentrasi total asam lemak mudah menguap, isovalerat dan isobutirat berada pada konsentrasi yang tinggi selama terjadinya penghambatan kinerja mikroorganisme oleh ammonia. Konsentrasi TAN pada digester biogas sebesar dan atau lebih dari $3 \mathrm{~g} / \mathrm{L}$ mengindikasikan bahwa seringkali produksi methan di bawah kondisi produksi optimumnya, oleh karena itu untuk mengkompensasinya masa tinggal substrate pada digester biogas harus diperpanjang atau digester biogas dioperasikan pada temperatur yang lebih rendah.

Kata kunci: inhibisi, total amonia nitrogen, amonia, produksi methan, asam lemak mudah menguap

ABSTRACT

This study investigated the effect of five different concentrations of total ammonia nitrogen (TAN) and free ammonia (FA) on the methane yield and digester performance under thermophilic conditions $\left(50^{\circ} \mathrm{C}\right)$. Five identical continuously fed digesters were used. The experiment was run for four times hydraulic retention time (HRT). Data were statitically analysed using the data Analysis Tool Pack available with the Microsoft Excel program. Different ammonia levels were obtained by pulsing urea to obtain the target level of TAN and FA, and to subsequently maintaining the concentration of ammonia levels by daily urea additions. The result showed a strong negative correlation between both TAN and FA concentrations and methane yield. The methane yield was reduced by $24,30,52$ and $66 \%$ in digesters that had TAN levels of 2.9, 3.6, 4.4 and $5.1 \mathrm{~g} / \mathrm{L}$, respectively, corresponding to $0.7,1.1,1.5$ and $1.8 \mathrm{~g} / \mathrm{L}$ FA. Total volatile fatty acid and especially isovaleric and isobutyric acid concentrations were elevated during ammonia inhibition. Concentration of TAN in the biogas digester exceeding $3 \mathrm{~g} / \mathrm{L}$ indicating that very often the full biogas potential is not achieved due to ammonia inhibition and that longer HRT should be used to compensate or a lower process temperature should be chosen.
\end{abstract}

Keywords: Inhibition, total ammonia nitrogen, free ammonia, methane yield, volatile fatty acid 


\section{INTRODUCTION}

Anaerobic digestion (AD) with liquid manure as the main substrate has a low biogas yield and is therefore dependent upon easily degradable substrates, e.g., industrial organic wastes, to make it economically viable (Nakakubo et al., 2008). Unfortunately, the availability of industrial organic waste is limited which has caused a setback in the establishment of new centralized biogas plants in Denmark (Raven and Gregersen, 2007).

Improved biogas production on a volume basis could be achieved by increasing the dry matter content in manure through solid-liquid separation. Since the dry fraction of manure has a higher ammonium and protein content than the original liquid manure, this strategy can have a negative effect on gas production due to ammonia inhibition. Methane yield from pig manure in a digester supplemented with $60 \% \quad(\mathrm{w} / \mathrm{w})$ of separated solid manure was $2001 \mathrm{CH}_{4} / \mathrm{kg}$ volatile solids (VS) compared to $3201 \mathrm{CH}_{4} / \mathrm{kg}$ VS in a reference digester operating solely on unseparated pig manure (Møller et al., 2007). This difference was attributed to the high level of total ammonia nitrogen (TAN) exceeding $5 \mathrm{~g} / \mathrm{l}$ in the digester processing the higher content of solid fraction pig manure. This value is greater than the TAN limit of $4 \mathrm{~g} / \mathrm{L} \mathrm{NH}_{4}-\mathrm{N}$ that caused a suboptimal $\mathrm{AD}$ process in the study of Angelidaki et al. (2005). Another study showed an ammonia inhibition threshold of about $2.5 \mathrm{~g} / \mathrm{L}$ of TAN for both the mesophilic and thermophilic stage of the ADprocessing of cattle manure, which had not previously been acclimatised to a high ammonia concentration (Hashimoto, 1986).

The ammonia inhibition phenomenon also occurs when anaerobic digesters operate with manure and proteinaceous biomasses as cosubstrates. However, ammonia inhibition is not related directly to total ammonium, but rather to the free ammonia (FA) concentration. Free ammonia is an active component in ammonia inhibition, since it is freely membrane-permeable (Siles et al., 2010). Suggested mechanisms responsible for ammonia inhibition are a change in the intracellular $\mathrm{pH}$, an increase in the maintenance energy requirement and inhibition of specific enzyme reactions (Whittmann et al., 1995). Even though there have been many studies on the subject, ammonia inhibition remains a problem for commercial biogas digesters performing co-digestion, and the imbalances caused by ammonia are still frequently reported (Nielsen and Angelidaki, 2008a). A better understanding of the ammonia inhibition could be of particular assistance to managers of commercial biogas plants who consider adding protein-rich biomass such as industrial organic waste or the solid fraction of separated manure. Several ammonia inhibition simulation studies have already been undertaken (Hashimoto, 1986; Hansen et al., 1998; and Nielsen and Ahring, 2007). All the studies used $\mathrm{NH}_{4} \mathrm{Cl}$ as a source of ammonia. However, since chloride might also inhibit the anaerobic process and it is impossible to differentiate the effect of ammonia and chloride, the present study used urea instead of $\mathrm{NH}_{4} \mathrm{Cl}$, and in this way restricts the inhibition to ammonia. In addition, to our knowledge only one previous study (Hashimoto, 1986) has examined the effect of more than four levels of TAN on the performance of anaerobic digesters using $\mathrm{NH}_{4} \mathrm{Cl}$ as the ammonia source and with a very short hydraulic retention time (HRT).

The objective of the present study was to evaluate the effect of five levels of TAN and FA on the methane yield and digester performance at a thermophilic temperature $\left(50^{\circ} \mathrm{C}\right)$ during inhibition period and also during recovery with no added urea. This may enable us to evaluate the extent of inhibition by ammonia in commercial thermophilic biogas digesters and give a precise estimate of methane yield reductions at specific ammonia levels.

\section{MATERIALS AND METHODS}

\section{Inoculum and Substrate}

Inoculum was obtained from a commercial biogas digester at Research Centre Foulum, Denmark, which treats pig manure, cattle manure, maize silage and industrial by-products. The commercial digester operates at $52^{\circ} \mathrm{C}$ and contents of total solids (TS), volatile solids (VS), $\mathrm{pH}$ value and TAN in the inoculum were $4.57 \%$; $3.35 \% ; 8.12 ; 1.82 \mathrm{~g} / \mathrm{L}$, respectively. Dairy cattle manure (DCM) from the lactation period was used as the substrate. Manure was collected from a storage pit at Research Centre Foulum every 14 days. Total ammonia nitrogen concentration, $\mathrm{pH}$, total N, TS and VS of the substrate were $2.10 \pm 0.38 \quad \mathrm{~g} / \mathrm{L}, \quad 7.09 \pm 0.30, \quad 3.85 \pm 0.63 \%$, $7.30 \pm 0.53 \%$, and $6.24 \pm 0.52 \%$, respectively.

\section{Experimental Design}

Five identical continuously fed digesters (R1, 
R2, R3, R4 and R5) were used. Each digester had $10 \mathrm{~L}$ capacity, with a $7 \mathrm{~L}$ working volume, 14-day HRT and were maintained at $50^{\circ} \mathrm{C}$. The experiment was started by filling all the digesters with $6.5 \mathrm{~L}$ of inoculum and $0.5 \mathrm{~L}$ of DCM on the first day. All the digesters were fed $500 \mathrm{~g}$ of DCM once every day through a tube, with the outlet submerged under the substrate level to avoid air ingress during the feeding process after the removal of the same amount of digested slurry from the digested slurry outlet.

On the day 21 after the start-up, urea (crystallized Ph.Eur Cat. No. 2880.362) was added at concentrations of $0.175,0.350,0.525$ and $0.700 \%(\mathrm{w} / \mathrm{w})$ to $\mathrm{R} 2, \mathrm{R} 3, \mathrm{R} 4$ and $\mathrm{R} 5$, respectively. No urea was added to R1, which served as the reference digester. The urea concentrations in the digesters were maintained by feeding the digesters daily with DCM and urea at the above concentrations. The experiment was run for $56 \mathrm{~d}$ (four times HRT) followed by a recovery period of $26 \mathrm{~d}$. All digesters were fed DCM without urea addition during the recovery period, thus the TAN concentration was gradually lowered by the effluent washout. This strategy was chosen to prevent a serious decline in methane production and to evaluate the recovery in biogas plant affected by different levels of ammonia inhibition.

\section{Analytical Methods}

Biogas was collected on a daily basis using aluminium-coated gas packs and measured using an acidified water displacement method. Gas samples were analysed for $\mathrm{CO}_{2}$ and $\mathrm{CH}_{4}$ content using a Perkin Elmer Clarus 500 gas chromatograph as described by Sutaryo et al. (2012). Volatile fatty acids $\left(\mathrm{C}_{2}-\mathrm{C}_{5}\right)$ were determined by gas chromatography (Hewlett Packard 6850A) with a flame ionization detector (FID) as described by Sutaryo et al. (2012). Total solids were determined by drying at $105^{\circ} \mathrm{C}$ for 24 hours. Ash was determined by combusting the dried samples $\left(550^{\circ} \mathrm{C}\right)$ for five hours, and VS calculated by subtracting the ash weight from the dry weight.

Total nitrogen was analyzed using the Kjeldahl standard method (APHA, 1995) and a Kjell-Foss 16200 auto analyzer (Foss Electric, Hillerod, Denmark). Total ammonia nitrogen was measured colorimetrically $(690 \mathrm{~nm})$ with a Merck ${ }^{\circledR}$ spectrophotometer (NOVA 60, $\mathrm{NH}_{4}{ }^{+}$test 1.00683.0001). $\mathrm{pH}$ value was measured using a pH meter (Metrohm AG, CH-9101 Herisau,
Switzerland).

The effect of ammonia inhibition on methane gas yield was defined by the methane generation ratio (MGR) (\%) (Nakakubo et al., 2008):

$$
\text { MGR }=\frac{\mathrm{B}_{\text {Inhibited reactor }}}{\mathrm{B}_{\text {Control }}} \times 100 \%
$$

where $B$ is the methane yield in terms of daily methane yield.

The concentration of $\mathrm{FA}\left(\mathrm{NH}_{3}-\mathrm{N}\right)$ in $\mathrm{g} / \mathrm{L}$ was calculated according to Anthonisen et al. (1976):

$$
\mathrm{NH}_{3}-\mathrm{N}=\frac{\left(\mathrm{NH}_{4}-\mathrm{N}\right) \cdot 10^{\mathrm{pH}}}{\frac{\mathrm{K}_{\mathrm{b}}}{\mathrm{K}_{\mathrm{w}}}+10^{\mathrm{pH}}} ; \frac{\mathrm{K}_{\mathrm{b}}}{\mathrm{K}_{\mathrm{w}}}=\exp \left(\frac{6344}{273}+\mathrm{T}\right)
$$

where $\mathrm{T}$ is temperature:

\section{RESULTS AND DISCUSSION}

\section{Methane Production}

Average methane yield in R1 (reference digester) was $171.05 \pm 15.45 \mathrm{~mL} / \mathrm{g}$ VS. Pind et al. (2003) reported a higher methane yield from digesters treating cattle manure $(213-220 \mathrm{ml} / \mathrm{g}$ VS). The dissimilarities can be attributed to differences in amount and types of bedding material, feeding of the cows, breed and growth stage of the animals (Hashimoto et al., 1981). Methane yield from each digester is summarized in Figure 1. The first day following urea addition, methane production in $\mathrm{R} 2, \mathrm{R} 3, \mathrm{R} 4$ and $\mathrm{R} 5$ dropped sharply, and then increased slowly and stabilized.

Figure 1 shows that the methane yield in R2 during treatment (mean TAN concentration = $3.02 \pm 0.11 \mathrm{~g} / \mathrm{L}$ ) dropped approximately $29 \%$ compared to the reference digester (TAN concentration $=2.26 \pm 0.12 \mathrm{~g} / \mathrm{L}$ ). Another study showed that AD with a TAN concentration of 3.2 $\mathrm{g} / \mathrm{L}$ resulted in a residual methane potential below $10 \%$, while for a digester with a TAN of $4.0 \mathrm{~g} / \mathrm{L}$ resulted in a residual methane potential of more than 20\% (Nielsen and Angelidaki, 2008b). Residual methane potential is the methane potential available in a material after digestion; a higher residual potential therefore suggests that a digester is operating below its optimum.

The effect of ammonia inhibition on the methane yield was statistically analysed based on the last three weeks of treatment data (d 37 to 56) following the substrate turnover more than 2.5 times. The methane production in this period was more stable compared to that of the earlier period 


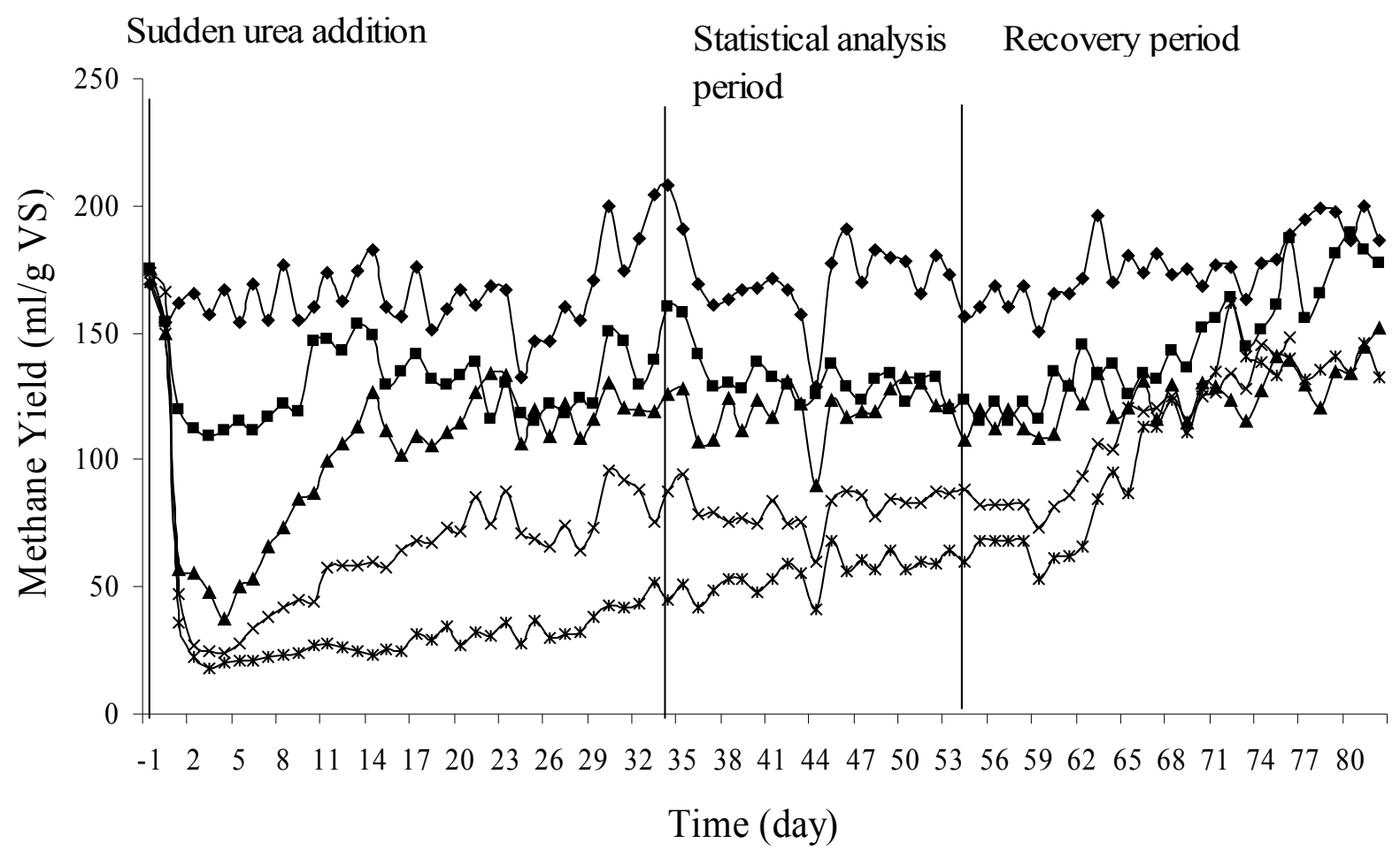

Figure 1. Daily Methane Yield (ml/g VS). ( ) R1/TAN $2.26 \mathrm{~g} \mathrm{~L}^{-1}$; (๘) R2/TAN $3.02 \mathrm{~g} \mathrm{~L}^{-1}$; ( $\mathbf{\Delta}$ ) R3/TAN 3.75 $\mathrm{g} \mathrm{L}^{-1} ;(\times)$ R4/TAN $4.54 \mathrm{~g} \mathrm{~L}^{-1}$ and $\left(^{*}\right)$ R5/TAN $5.23 \mathrm{~g} \mathrm{~L}^{-1}$. Note: A gas decrease on day 46 was because of a problem with the incubator

(Figure 1). Furthermore, the standard deviation during this period was $5.49,4.79,5.98,5.71$, and $10.27 \%$ in R1, R2, R3, R4 and R5, respectively, which was much lower than for $\mathrm{d} 1$ to 36 at 9.60 , $11.13,27.37,32.69$ and $28.05 \%$, respectively. Total ammonia nitrogen during this period was lower than the average TAN for days 15-35 (Table 1) due to the low TAN concentration of the substrate. A regression analysis of days 37-56 data (determined using the Data Analysis Tool Pack available with the Microsoft Excel program) revealed a strong negative correlation $(\mathrm{Y}=$ $\left.-21.798 \mathrm{X}+145.06, \mathrm{R}^{2}=0.98\right)$ between the TAN concentration and the methane generation ratio (Figure 2). This value accords well with the findings of the Nakakubo et al. (2008) study who added pulses of ammonia $\left(\mathrm{NH}_{4} \mathrm{Cl}\right)$ to digesters treating pig manure and found $\mathrm{R}^{2}=0.91$. Methane yields in R1, R2, R3, R4 and R5 were 168.31, $128.54,118.33,80.56$ and $56.93 \mathrm{~mL} / \mathrm{g} \mathrm{VS}$, respectively, corresponding to MGR values of $100,76.37,70.30,47.86$ and $33.82 \%$.

This study also found a strong negative correlation $\left(\mathrm{Y}=-46.68 \mathrm{X}+117.62, \mathrm{R}^{2}=0.96\right)$ between FA concentration and the methane generation ratio (Figure 2). The FA concentration in $\mathrm{R} 2$ was $0.7 \mathrm{~g} / \mathrm{L}$ and the methane yield was decreased by $24 \%$ compared to the reference digester (FA $0.5 \mathrm{~g} / \mathrm{L}$ ). This is an important value since R2 is the least inhibited of R2-R5. This result is in accordance with Angelidaki and Ahring (1993), where an increase in the FA concentration from $0.55 \mathrm{~g} / 1$ to $0.65 \mathrm{~g} / \mathrm{L}$ in a digester treating cattle manure resulted in an approximately $24 \%$ lower methane yield. Moreover, there are three determinants of FA concentration, namely TAN concentration, temperature and $\mathrm{pH}$ (Hansen et al., 1998). The $\mathrm{pH}$ values during ammonia inhibition in the present experiment were $7.95 \pm 0.05 ; \quad 8.05 \pm 0.05$; $8.16 \pm 0.10 ; 8.24 \pm 0.12$ and $8.26 \pm 0.15$ in R1, R2, R3, R4 and R5, respectively.

\section{Effect of Urea Addition on VFA Dynamics in the Liquid Phase}

Total VFA dynamics following urea addition is shown in Figure 3. The day after initial urea addition, total VFA concentration remained fairly 
Table 1. Total Ammonia Nitrogen (g/L) and Free Ammonia Concentrations (mg/L) of R1, R2, R3, R4, R5, and Substrate from day 15-35 and Day 36-56

\begin{tabular}{lccccc}
\hline & \multicolumn{4}{c}{ Period (days) } \\
\cline { 2 - 3 } \cline { 5 - 6 } & \multicolumn{2}{c}{$15-35$} & & \multicolumn{2}{c}{$36-56$} \\
\cline { 2 - 3 } \cline { 5 - 6 } & TAN $\left(\mathrm{g} \mathrm{L}^{-1}\right)$ & $\mathrm{FA}\left(\mathrm{g} \mathrm{L}^{-1}\right)$ & & TAN $\left(\mathrm{g} \mathrm{L}^{-1}\right)$ & $\mathrm{FA}\left(\mathrm{g} \mathrm{L}^{-1}\right)$ \\
\hline R1 & $2.37 \pm 0.08$ & $0.50 \pm 0.03$ & & $2.15 \pm 0.06$ & $0.48 \pm 0.03$ \\
R2 & $3.05 \pm 0.09$ & $0.77 \pm 0.06$ & & $2.93 \pm 0.10$ & $0.71 \pm 0.03$ \\
R3 & $3.75 \pm 0.13$ & $1.13 \pm 0.12$ & & $3.62 \pm 0.13$ & $1.09 \pm 0.11$ \\
R4 & $4.48 \pm 0.13$ & $1.45 \pm 0.11$ & & $4.43 \pm 0.10$ & $1.49 \pm 0.17$ \\
R5 & $5.31 \pm 0.08$ & $1.58 \pm 0.10$ & & $5.09 \pm 0.20$ & $1.79 \pm 0.15$ \\
Substrate & $2.09 \pm 0.35$ & $0.07 \pm 0.04$ & & $1.90 \pm 0.31$ & $0.06 \pm 0.02$ \\
\hline
\end{tabular}

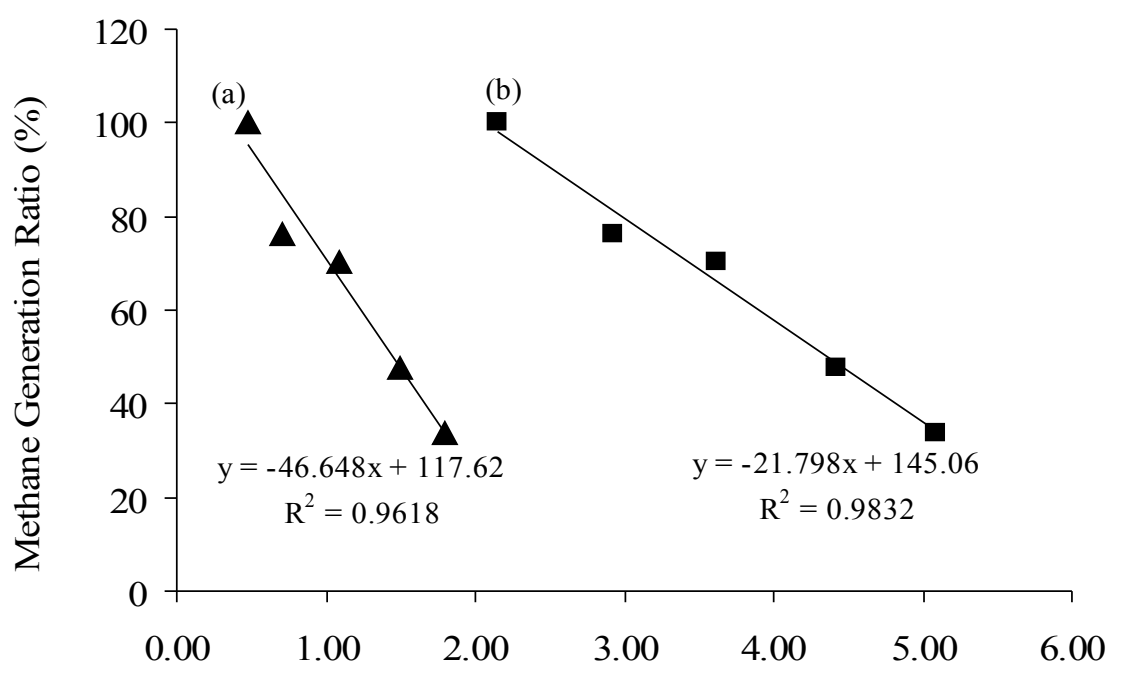

Free Ammonia $\left(\mathrm{NH}_{3}\right)$ or Total Ammonia Nitrogen

Concentration $(\mathrm{g} / \mathrm{L})$

Figure 2. Methane Generation Ratio Corresponding to: a) ( $\mathbf{\Delta}$ ) Free Ammonia Concentration and b) ( Total Ammonia Nitrogen Concentration

constant in all digesters, but then increased sharply before decreasing to a stable but elevated level in all the digesters, except for R1 where it decreased gradually and then stabilized at a low concentration. The high initial total VFA concentration in $\mathrm{R} 1$ can be attributed to the inoculum. Subsequent variations in total VFA in R1 were the result of total VFA variations in the substrate (Figure 3), which was changed every 14 days.
The delayed response in total VFA concentration following urea addition suggests that ammonia inhibition of the organisms was not immediate. The average total VFA for d 37 to 56 were $282,2163,2726,3933$, and $6503 \mathrm{mg} / \mathrm{L}$ for $\mathrm{R} 1, \mathrm{R} 2, \mathrm{R} 3, \mathrm{R} 4$ and R5, respectively. This is in accordance with Braun et al. (2003) who found that as the percentage of flotation sludge from poultry slaughterhouse to cattle manure increased from 5 to $20 \%$, the VFA concentration increased 


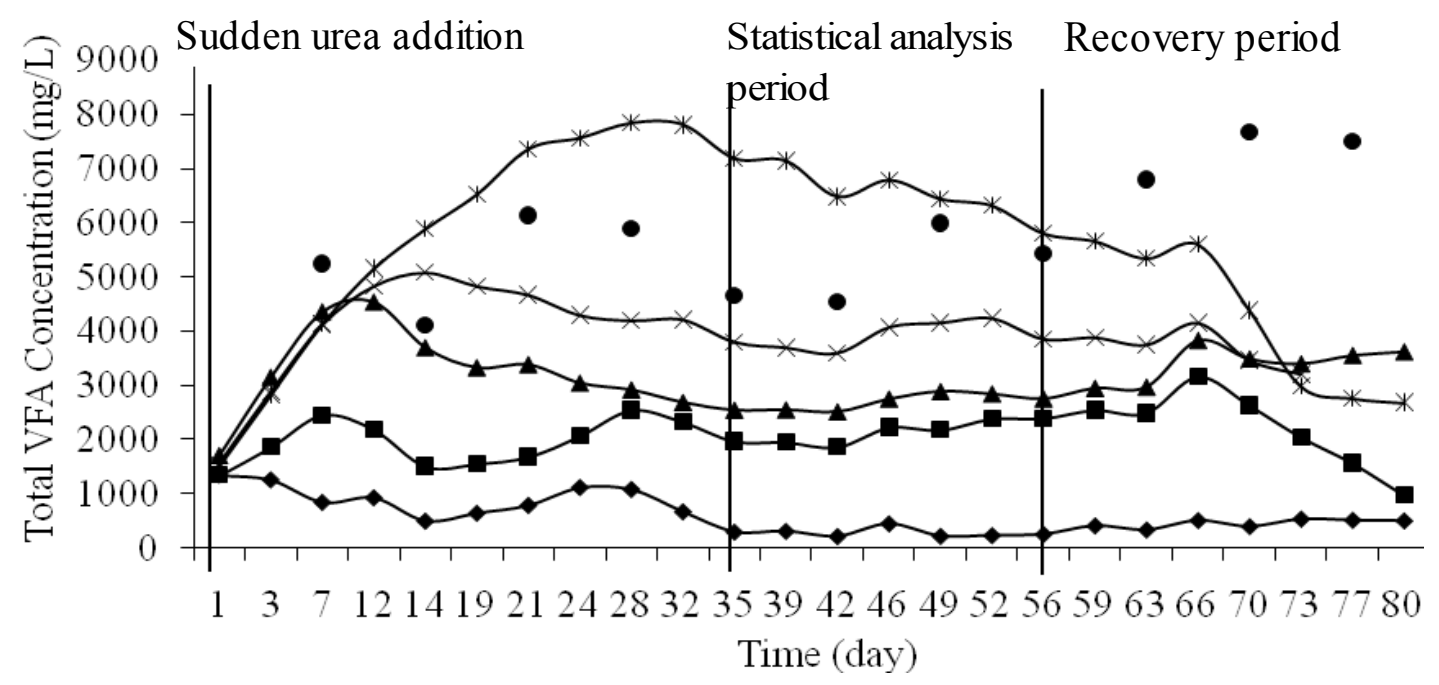

Figure 3. Total VFA Concentration. ( ) R1/TAN $2.26 \mathrm{~g} \mathrm{~L}^{-1}$; (凶) R2/TAN $3.02 \mathrm{~g} \mathrm{~L}^{-1}$; ( $\mathbf{\Delta}$ ) R3/TAN $3.75 \mathrm{~g}$ $\mathrm{L}^{-1} ;(\times)$ R4/TAN $4.54 \mathrm{~g} \mathrm{~L}^{-1}(*) \mathrm{R} 5 / \mathrm{TAN} 5.23 \mathrm{~g} \mathrm{~L}^{-1}$ and $(\bullet)$ substrate.

from about $100-200$ to $1000-2000 \mathrm{mg} / \mathrm{l}$ (measured on acetic acid concentration). However, it was not feasible to figure out the absolute total VFA concentration, which would indicate the state of the $\mathrm{AD}$ process. Each process has its own "normal" level of VFA concentration, determined by substrate composition or the operating conditions (Angelidaki et al., 1993). The peak of total VFA and some of the individual VFAs on day 66 were due to the feed since VFA in the feed was high during this period (Figure 3).

Individual VFA concentrations analysis showed (data not shown) that acetic and propionic acid were the most abundant intermediates. Acetic acid in R2, R3, R4 and R5 decreased from day 7, 11,14 and 35 , respectively. The rapid metabolism of acetic acid in R2, R3, and R4 suggests a rapid methanogenic adaptation, while the very high ammonia concentration in R5 shows strong methanogenic inhibition and, consequently, very slow adaptation. However, total VFA concentrations were persistently at an elevated level due to an increase in propionic and isobutyric acid concentrations throughout the urea-addition period. The slower metabolism of butyric, isovaleric and valeric acids to acetate would indicate a slower adaptation of the acetogenic organisms.

Individually, isobutyric and isovaleric acid accumulated during ammonia inhibition, as was also the case for valeric acid but to a lesser extent.
This result is in agreement with (Nakakubo et al., 2008) that isobutyric, butyric and isovaleric acids were useful process indicators during ammonia inhibition.

\section{Recovery of the Process Following Ammonia Inhibition}

The methane yield during the recovery period from d 57 to 82 is shown in Figure 1. If a complete recovery can be defined as the time when the methane yield is similar to the noninhibited digester, R2 started to recover on the day 23 after cessation of urea addition (Figure 1). Furthermore, the results of statistical analysis (determined by Data Analysis Tool Pack available with the Microsoft Excel program) show that the methane yield in R1 and R2 from d 23 to 26 was not significantly different $(\mathrm{P}>0.05)$. Nielsen and Angelidaki (2008b) reported that a digester operating with added $\mathrm{NH}_{4} \mathrm{Cl}$ to give $1.2 \mathrm{~g} / \mathrm{L} \mathrm{FA}$ concentration, with the same recovery strategy, needed 29 days to recover methane gas production to pre-inhibition levels. The shorter recovery period in the work presented here was attributed to a shorter HRT, lower temperature and lower FA concentration in R2 than was recorded by Nielsen and Angelidaki (2008b). As reported by Hansen et al. (1998), the FA concentration, which is the cause of methanogen inhibition, is dependent on the TAN concentration, temperature, and $\mathrm{pH}$. Increasing the temperature 
and $\mathrm{pH}$ leads to an increase in the FA concentration. Surprisingly, the recovery was faster in R4 and R5 than in R3 (Figure 1). This phenomenon could be because: 1) the microorganisms in these digesters were better adapted to high ammonia concentrations; 2) the amount of non-degraded organic material in these digesters was higher than in R3 because less methane was being produced during the inhibition period. The efficiency of recovery not only depends on the TAN concentration but also on the substrate composition. Total ammonia concentration at the end of experiment was 2.59, 2.63, 2.85 and $2.92 \mathrm{~g} / \mathrm{L}$ for R1, R2, R3 and R5, respectively.

\section{CONCLUSIONS}

Methane yield was strongly inhibited by increased levels of $\mathrm{NH}_{3}$. The yield was approximately $24 \%$ lower in a digester with a TAN concentration of $2.93 \mathrm{~g} / \mathrm{L}(\mathrm{FA} 0.71 \mathrm{~g} / \mathrm{L})$ compared to $2.15 \mathrm{~g} / 1$ (FA $0.48 \mathrm{~g} / \mathrm{L}$ ) in the reference digester. Total VFA, isobutyric and isovaleric acid concentrations accumulated during ammonia inhibition, thus these parameters and the methane yield were useful indicators of ammonia inhibition. Recovery from ammonia inhibition was faster in the digester with the higher TAN concentration, indicating that microorganisms here were already adapted.

\section{ACKNOWLEDGMENTS}

The research was financed by the research and development programme for renewable energy (EUDP).

\section{REFERENCES}

APHA. 1995. Standard Methods for Examination of Water and Waste Water, $19^{\text {th }}$ ed. Washington, D.C. American Public Health Association.

Angelidaki, I and B.K. Ahring. 1993. Thermophilic anaerobic digestion of livestock waste: effect of ammonia. Appl. Microbiol. Biotechnol. 38: 560-564.

Angelidaki, I., L. Ellegaard and B.K. Ahring. 1993. A mathematical model for dynamic simulation of anaerobic digestion of complex substrates, focusing on ammonia inhibition. Biotechnol. Bioeng. 42: 159-166.

Angelidaki, I., K. Boe and L. Ellegaard. 2005.
Effect of operating conditions and reactor configurations on efficiency of full-scale biogas plants. Water Sci. Technol. 52: 189194.

Anthonisen, A.C., R.C. Loer, T.B.S. Prakasam and E.G. Srinath. 1976. Inhibition of nitrification by ammonia and nitrous acid. J. Wat. Pollut. Contr. Federation. 48: 835-852.

Braun, R., E. Brachtl and M. Grasmug. 2003. Codigestion of proteinaceous industrial waste. Appl. Biochem. Biotechnol. 109: 139153.

Hansen, K.H., I. Angelidaki and B.K. Ahring. 1998. Anaerobic digestion of swine manure inhibition by Ammonia. Water Res. 32: 5-12.

Hashimoto, A.G., Y.R. Chen and V.H. Varel. 1981. Theoretical aspects of anaerobic fermentation: state of the art. In: Livestock waste: a renewable resource. Proceeding of the Fourth International Symposium on Livestock Wastes. ASAE, St Joseph, Michigan. p. 86-91.

Hashimoto, A.G. 1986. Ammonia inhibition of methanogenesis from cattle wastes. Agri. Wastes 17: 241-261.

Møller, H.B, A.M. Nielsen, R. Nakakubo, H.J. Olsen. 2007. Process performance of biogas digesters incorporating pre-separated manure. Livestock Sci. 112:217-223.

Nakakubo, R., H.B. Møller, A.M. Nielsen, J. Matsuda. 2008. Ammonia inhibition of methanogenesis and identification of process indicators during anaerobic digestion. Environ. Eng. Sci. 25: 1487-1496.

Nielsen, H.B and B.K. Ahring. 2007. Effect of tryptone and ammonia on the biogas process in continuously stirred tank reactors treating cattle manure. Environ. Technol. 28: 905914.

Nielsen, H.B and I. Angelidaki. 2008a. Codigestion of manure and industrial organic waste at centralized biogas plants: process imbalances and limitations. Water Sci. Technol. 58(7): 1521-1528.

Nielsen, H.B and I. Angelidaki. 2008b. Strategies for optimizing recovery of the biogas process following ammonia inhibition. Bioresour. Technol. 99:7995-8001.

Pind, P.F., I. Angelidaki and B.K. Ahring. 2003. Dynamics of the anaerobic process: effects of volatile fatty acids. Biotechnol. Bioeng. 82: 791-801.

Raven, R.P.J.M and K.H. Gregersen. 2007. Biogas plants in Denmark: successes and setbacks. 
Renew. Sustain. Energy Rev: 11: 116-132.

Siles, J.A., J. Brekelmans, M. A. Martin, A. F. Chicas and A. Martin. 2010. Impact of ammonia and sulphate concentration on thermophilic anaerobic digestion. Bioresour. Technol. 101: 9040-9048.

Sutaryo, S., A.J. Ward and H.B. Møller. 2012. Thermophilic anaerobic co-digestion of separated solids from acidified dairy cow manure. Bioresour. Technol. 114: 195-200.

Whittmann, C., A.P. Zeng and W.D. Deckwer. 1995. Growth inhibition by ammonia and use of $\mathrm{pH}$-controlled feeding strategy for effective cultivation of Mycobacterium chlorophenolicum. Appl. Microbiol. Biotechnol. 44: 519-525. 